\author{
А.Ф. Гавриленков \\ SMoleński Uniwersytet Państwowy \\ E-MAIL: ALEKSEJ.GAVRILENKOV@MAIL.RU
}

\title{
ОСОБЕННОСТИ РАЗВИТИЯ РЕЛИГИИ В УСЛОВИЯХ ГЛОБАЛИЗАЦИИ
}

Человечество стоит на пороге создания глобального мира. Глобализация становится реальностью современного общества. Проявления глобализации отмечаются в экономической, политической, правовой и духовной сферах общества. В духовной сфере наблюдается процесс унификации.

Глобализация затрагивает, прежде всего, процессы, происходящие на пограничье. В первую очередь это касается социально-культурного аспекта пограничья (пограничье - пространство социально-культурных контактов между двумя или более нациями (этносами)). Именно на пограничье происходит создание новой социально-культурной среды, формирование нового человека.

На пограничье цивилизаций происходит взаимодействие религий, которое может осуществляться как через столкновение, так и через сотрудничество религий, вырабатываются некие новые черты (элементы), которые показывают сходство и близость религий. Примером таких религий могут быть сикхизм, афро-христианские религии, греко-католическая религия. Сикхизм соединяет в себе черты ислама и индуизма. Афро-христианские религии - образование, возникшее на стыке африканских религий и христианства. Среди современных нетрадиционных религий и культов также есть религии, которые соединяют в себе черты других религий. Так, кришнаизм сочетает в себе черты индуизма и буддизма.

Вопрос взаимодействия религий достаточно сложный. Известно, исторически, что между религиями, даже в рамках одной цивилизации происходила борьба. Например, между католицизмом и право- 
славием, протестантизмом и католицизмом в христианстве, щиизмом и суннизмом в исламе.

Исторически такие религии пограничья появились давно. Однако, в силу ряда причин не получили дальнейшего развития. Так, в конце $\mathrm{XV}$ века появился сикхизм. К таким религиям, внутри христианской цивилизации, например, можно отнести униатские религии. Грекокатолическая религия, возникшая в 1596 году в Бресте - типичный пример религии пограничья в рамках одной цивилизации. Догматически греко-католики тяготеют к католикам, обрядово - к православным. В результате только на польско-украинском пограничье в начале XXI века выделяют пять типов религиозной идентичности греко-католиков пограничья [Лыпка 2012: 81].

Греко-католическая (униатская) церковьдолжна была своим появлением создать условия для постепенного перехода православных верующих в католицизм․ В связи с чем Греко-католическая (униатская) церковь задумывалась католической церковью как переходное от православия к католицизму явление в духовной жизни русского народа в составе еще польского государства. «3 боку католиків уніатам довелося витримати не менш серйозний натиск, аніж з боку православних. Частина католицького єпископату наполягала на ліквідаії унії (яка, всупереч сподіванням, посилила неспокій у державі) та прямій католицькій місії на Сході. Як місійне поле розглядалася й уніатска церква, з рядів якої до католицтва перейшла майже вся шляхта. Католицька ієрархія не допускала думки про рівність з уніатською ієрархією: навить суфрагани (заступники католицьких єпископів) вважали себе вищими від уніатських ієрархів» («Со стороны католиков униатам пришлось испытывать не менее серьезный нажим, чем со стороны православных. Часть католического епископата настаивала на ликвидации унии (которая, вопреки ожиданиям, усилила беспокойство в державе) и откровенной католической миссии на Востоке. Как миссионерское поле рассматривалась и униатская церковь, из рядов которой в католичество перешла почти вся шляхта. Католическая иерархия не допускала мысли о равенстве с униатской иерархией...»

1 Перед первым разделом Речи Посполитой 1772 году, на ее территории действовали восемь униатских епархий (Канфесіi на Беларусі (к. XVIII-XX ст.) / В.В. Грыгор'ева, У.М. Завальнюк, У.І. Навіцкі, А.М. Філатава; Наук. ред. У.І. Навіцкі. - Минск: ВП «Экаперспектива», 1998. C. 5). 
[Крижанівський, Плохій 1994: 55]. Переходный характер униатской церкви подчеркивал ее временный характер [Мараш 1971: 97].

Однако, дальнейшее развитие этой религии не пошло, так как её стали использовать в своих интересах различные политические и идеологические силы.

Религия в современном мире будет играть специфическую роль, став инструментом глобализации духовной сферы. В развитии религии в условиях глобализации будут проявляться несколько тенденций.

Первая тенденция будет состоять в том, что будет идти процесс расширения группы мировых религий. В XX веке к мировым религиям относили буддизм, христианство и ислам. Однако, ещё в начале $\mathrm{XX}$ века западноевропейский ученый М. Вебер к мировым религиям причислил индуизм, конфуцианство, буддизм, христианство, ислам [Вебер 1985: 43]. На рубеже XX-XXI вв. западноевропейские исследователи относят к мировым религиям буддизм, христианство, ислам, иудаизм, индуизм, даосизм, конфуцианство, зороастризм [Коллинз 2004: 451].

Вторая тенденция будет заключаться в следующем. Мировые религии будут постепенно уступать свои позиции другим религиям. Однако, заметим, что это достаточно долгий процесс. Численность верующих мировых религий будет снижаться. Консерватизм вероучений мировых религий будет способствовать оттоку части верующих от этих религий. Однако, рассчитывать на то, что численность верующих, принадлежащих к мировым религиям, будет быстро уменьшаться, не приходится. Сравнивая темпы развития традиционных религий и нетрадиционных религиозных движений в начале XXI века, Р.С. Истамгалин замечает, что «если по количеству последователей новые культы значительно уступают традиционным религиям, то по темпам роста числа организаций они являются самой быстрорастущей группой» [Истамгалин 2006: 123].

Рассмотрим данную тенденцию в развитии религий в современном мире. Для этого проанализируем данные о количестве верующих в мире за 110 лет - с 1900 по 2010 гг. За основу Таблицы №1 была взята таблица из книги Michel Clévenot «L'etat des religions dans le monde», написанной автором ещё в 1987 году, а также использованы интернет-материалы [Clévenot 1987: 14]. Эти данные сравним с данными по росту населения за указанный период. 
Таблица № 1. Количество верующих основных религий в период с 1900 по 2010 гг.

\begin{tabular}{|l|r|r|r|r|}
\hline & \multicolumn{1}{|c|}{1900} & \multicolumn{1}{c|}{ 2000 } & \multicolumn{1}{c|}{$\mathbf{2 0 0 4}$} & \multicolumn{1}{c|}{$\mathbf{2 0 1 0}$} \\
\hline Католицизм & 226419400 & 1132541500 & 968000000 & 1167000000 \\
\hline Протестантизм & 142577100 & 589327000 & 466000000 & 470000000 \\
\hline Православие & 115897700 & 199819000 & 218000000 & 245080000 \\
\hline Иудаизм & 12269800 & 20173600 & 14000000 & 24510000 \\
\hline Ислам & 200102200 & 1200653000 & 1000000000 & 941090000 \\
\hline Буддизм & 127159000 & 359092100 & 324000000 & 490150000 \\
\hline Индуизм & 203033300 & 859252100 & 780000000 & 846330000 \\
\hline Джайнизм & 1000000 & 4000000 & 5000000 & 4900000 \\
\hline Сикхизм & 2960600 & 23231700 & 19000000 & 23000000 \\
\hline Вера Бахаи & 100000 & 7000000 & 6000000 & 7000000 \\
\hline $\begin{array}{l}\text { Всего населения } \\
\text { в мире }\end{array}$ & 1600000000 & 6100000000 & 6055049000 & 6821300000 \\
\hline
\end{tabular}

Анализ роста населения в мире за 1900-2010 гг. показал увеличение населения в 4,26 раза и выявил следующие тенденции. Вопервых, темпы роста ряда религий значительно опережают темпы роста населения в мире. К таким религиям относятся Вера Бахаи, сикхизм, ислам, католицизм. Увеличение составляет соответственно в $70: 7,77: 4,7: 5,15$ раз.

Во-вторых, ряд религий незначительно отстает от темпов роста населения в мире. К таким религиям относятся индуизм, джайнизм, буддизм, протестантизм (всех деноминаций). Соотношение составляет соответственно $4,17: 4,9: 3,85: 3,29$ раза.

B-третьих, ряд религий, темпы развития которых уже значительно уступают темпам роста населения в мире. К таким религиям, согласно проанализированным данным, относятся православие, иудаизм. Соотношение следующее: $2,11: 1,99$ раза соответственно.

Таким образом, мы видим, что происходит изменение внутри общепризнанной классификации религий. Количество мировых религий будет изменяться.

Постепенно будет замедляться рост численности верующих мировых и ряда народностно-национальных религий. Будет проявляться противоречие: численность верующих отдельных религий будет расти медленнее, чем численность населения в мире в целом.

Третьей тенденцией станет расширение группы синкретических нетрадиционных религий и культов. Возникновение таких религий 
как, например, Вера Бахаи, Международное общество сознания Кришны (МОСК) будет идти далее. Их нетрадиционность основана на том, что каждая такая религия или культ включает элементы, как правило, традиционных для общества религий.

Постепенно в мире будут появляться, на основе нетрадиционных религий, религии, которые будут соответствовать характеру глобальных процессов - религии глобализирующегося мира (Схема № 1).

Схема № 1

\begin{tabular}{|c|c|c|c|c|c|c|}
\hline \multicolumn{7}{|c|}{ РЕЛИГИИ ГЛОБАЛИЗИРУЮЩЕГОСЯ МИРА } \\
\hline \multicolumn{7}{|c|}{ Вера Бахаи } \\
\hline \multicolumn{7}{|c|}{ МИРОВЫЕ РЕЛИГИИ } \\
\hline Буддизм & $\begin{array}{c}\text { Между- } \\
\text { народное } \\
\text { общество } \\
\text { сознания } \\
\text { Кришны }\end{array}$ & $\begin{array}{c}\text { Конфуци- } \\
\text { анство }\end{array}$ & Даосизм & $\begin{array}{c}\text { Христианс- } \\
\text { тво }\end{array}$ & Ислам & Иудаизм \\
\hline \multicolumn{6}{|c|}{ НАРОДНОСТНО-НАЦИОНАЛЬНЫЕ РЕЛИГИИ } & \\
\hline \multicolumn{2}{|c|}{ Индуизм } & \multicolumn{2}{|c|}{ Джайнизм } & \multicolumn{2}{|c|}{ Сикхизм } & Синтоизм \\
\hline
\end{tabular}

Анализ развития религий за 1900-2010 гг. показал, что Вера Бахаи имеет самые высокие показатели к развитию в современном мире. В конце XX века немецкий ученый Петер Герлитц не без оснований ставил вопрос о том, что, следует ли считать Религию (Веру) Бахаи мировой религией [Герлитц 2001: 167-169]? Ответ ученого носит конкретный характер: «... «религия единения», как называли свое детище основатели религии Бахаи, оказывается в контексте мировой истории религий лишь одним из набросков, одним из возможных эскизов и вариантов наряду с другими религиями» [Герлитц 2001: 169].

Вера Бахаи представляет собой религию нового качества, о чем свидетельствуют следующие данные. С одной стороны, религию Вера Бахаи на рубеже веков стремятся определить как мировую религию, так как она обладает чертами универсализма. С другой стороны, в учении Вера Бахаи четко просматривается черта, которая ставит её над мировыми и народностно-национальными религиями. Она претендует стать религией, которая сможет объединить другие религии. Назовем несколько признаков нового качества религии Веры Бахаи.

Во-первых, в данной религии объявляется, что бог един в мире. Во-вторых, независимыми явителями вселенского Пророчества 
называются Заратуштра, Авраам, Моисей, Будда, Христос, Мухаммед, Баба, Бахаулла, Кришна [Герлитц 2001: 154, Иоаннесян 2003: 160]. Последователями и продолжателями учения называются иудейские пророки Исаия, Иеремия, Иезекиль, а также израильские цари Давид и Соломон [Иоаннесян 2003: 160].

Вера Бахаи не сможет достаточно быстро стать религией глобализирующегося мира, так как количество последователей данной религии значительно уступает количеству верующих мировых религий, однако условия к этому все же есть.

Подводя итог вышеизложенному, заметим, что логика современного развития в условиях глобализации мира убедительно показывает, что религия сохранит своё влияние в обществе вне зависимости от того, имеет ли религия отношение к народностно-национальным, мировым или современным нетрадиционным религиям. В будущем будет постепенно меняться картина распространения и развития религий в глобальном мире. Вероятно, что в ближайшем будущем появятся религии, которые будут отражать ценности глобализирующегося мира.

\section{Литература}

Антес П. (2001), Религии современности. История и вера, «Прогресс-Традиция», Москва.

Вебер М. (1985), Хозяйственная этика мировых религий, [w:] Работы М. Вебера по социологии религии и идеологии, Москва.

Герлитц П. (2001), Вера Бахаи, [w:] П. Антес, Религии современности. История и вера, «Прогресс-Традиция», Москва.

Грыгор'ева В.В., Завальнюк У.М., Навіцкі У.І., Філатава А.М. (1998), Канфесіі на Беларусі (к. XVIII-XX ст.), ВП «Экаперспектива», Мінск.

Иоаннесян Ю.А. (2003), Вера Бахаи, «Петербургское Востоковедение», Санкт-Петербург.

Истамгалин Р.С. (2006), Нетрадиционная религиозность в Баикортостане, «Социология», № 3-4.

Коллинз Р. (2004), Социологическая интуиция: Введение в неочевидную соииологию, [w:] Личностно-ориентированная соииология, «Академический Проект», Москва. 
Крижанівський О.П., Плохій С.М. (1994), І̇сторія иеркви та релігійної думки в Украӥні. У трьох книгах, Книга 3. Кінець XVI - середина XIX століття, «Либідь», Київ.

Личностно-ориентированная социология, (2004), «Академический Проект», Москва.

Лыпка О. (2012), Религиозная идентичность на пограничье культур, [w:] Debaty Artes Liberales, T. VI. Пограничье культур - культуры пограничья, Варшава.

Мараш Я. (1971), Ватикан и католическая церковь в Белоруссии (1596-1795). «Вышэйшая школа», Минск.

Мещеряков Д.Н. (2007), Глобализация в религиозной сфере общественного бытия, Автореф. дис. ... канд. филос. наук: 09.00.13. Омск.

Работы М. Вебера по социологии религии и идеологии, (1985), Москва.

Clévenot M. (1987), L'etat des religions dans le monde. Éditions La Découverte et Éditions du Cerf, Paris.

http://eredraug.livejournal.com/94656.html [дата обращения 31.05.2014 г.].

\section{SUMMARY}

Specific properties of the development of religion in the contekst of globalization

Globalization is a reality of the modern world. Religion in the future will become an instrument of globalization spiritual sphere. Gradually in the world will appear religion that will correspond to the character of global processes, the religion of the globalizing world.

KEYWORDs: globalization, religion, world religions, narodnostna-national religion, modern non-traditional religions, the Baha'i Faith 